We thank Dr. A. L. Turnbull, consultant physician at the London Hospital for permission to report the second case and Dr. David Fisher, Cardiff Royal Infirmary, for preparing the report of this case.

\section{References}

Branca, M., et al. (1971). Clinical and Experimental Immunology, 9, 853. Brodovsky, H. S., et al. (1968). Archives of Internal Medicine, 121, 71.
Froom, D. W., et al. (1972). Archives of Pathology, 94, 547.

Hirsch, M. S., Allison, A. C., and Harvey, J. J. (1969). Nature, 223, 739. Holmes, M. C., and Burnet, F. M. (1963). Annals of Internal Medicine, 59, 265.

Hyman, L. R., et al. (1973). Fournal of Pediatrics, 82, 207.

Leonard, B. J. (1957). Lancet, 1, 1356.

Lewis, M. G., Loughridge, L. W., and Phillips, T. M. (1971). Lancet, 2, 134.

Loughridge, L. W., and Lewis, M. G. (1971). Lancet, 1, 256.

Mellors, R. C., et al. (1971). Fournal of Experimental Medicine, 133, 113.

Recher, L., et al. (1966). National Cancer Institute Monographs, 22, 459.

Scott, R. Bodley (1957). Lancet, 1, 1162.

\title{
Renal Insensitivity to Frusemide Caused by Chronic Anticonvulsant Therapy
}

\author{
SUHAIL AHMAD
}

British Medical Fournal, 1974, 3, 657-659

\section{Summary}

The diuretic response to $20-\mathrm{mg}$ and $40-\mathrm{mg}$ oral doses of frusemide was significantly smaller in a group of epileptic patients on chronic anticonvulsant therapy than in a group of normal staff members. Furthermore, the peak response was considerably delayed in the epileptic patients. The difference in the volume of diuresis was maintained after intravenous injection of $20 \mathrm{mg}$ of frusemide. It is suggested that the sensitivity of the renal tubule to the diuretic action of frusemide is reduced by anticonvulsant therapy and that there may also be delayed absorption of the drug from the gastrointestinal tract.

\section{Introduction}

In chronic epileptics in a residential centre the incidence of dependent oedema seemed to be greater than would be expected in a normal population and the response to diuretic therapy was poor. To evaluate this impression a study was undertaken to compare the diuretic response produced by frusemide in a group of epileptic patients on chronic anticonvulsant therapy and a group of normal staff members.

\section{Subjects and Methods}

A group of 30 long-stay patients at the Chalfont Centre for Epilepsy was studied. Patients were aged $20-48$ years and were in good health other than their chronic epilepsy. None had oedema, heart failure, or renal disease. Blood urea, serum electrolytes, creatinine, creatinine clearance, and 24-hour urinary excretion of sodium and potassium were normal. The results of investigations are shown for 17 patients in table I. All were receiving phenytoin sodium in doses of $200-400 \mathrm{mg}$ daily and

Chalfont Centre for Epilepsy, Chalfont St. Peter, Buckinghamshire SL9 ORJ

SUHAIL AHMED, B.sC., M.B., Assistant Physician phenobarbitone 60-180 mg daily. In addition, three were receiving carbamazepine, two pheneturide, two ethosuximide, three diazepam, and one chlordiazepoxide.

The normal subjects were of a similar age range, in good health, and not receiving drug therapy of any kind and comprised nurses, technicians, and doctors whose informed consent was obtained. The investigation was approved by the hospital ethical committee.

The study was placebo controlled, double blind, and randomized. A period of $\mathbf{4 8}$ hours was allowed between treatments for fluid balance to be restored. No restrictions were placed on fluid intake during the study and the subjects were allowed normal breakfast at 07.15 hours. Treatments were administered at 08.00 hours after emptying the bladder, and urine collections were subsequently made at hourly intervals for six hours after oral frusemide (20 mg and $40 \mathrm{mg}$ ) and every 15 minutes for 105 minutes after intravenous administration of the drug $(20 \mathrm{mg})$. The diuretic response was complete by the end of these periods in all subjects. The volume of each urine collection was measured and the difference between the urine volumes in the patients and normal subjects analysed by Student's $t$ test.

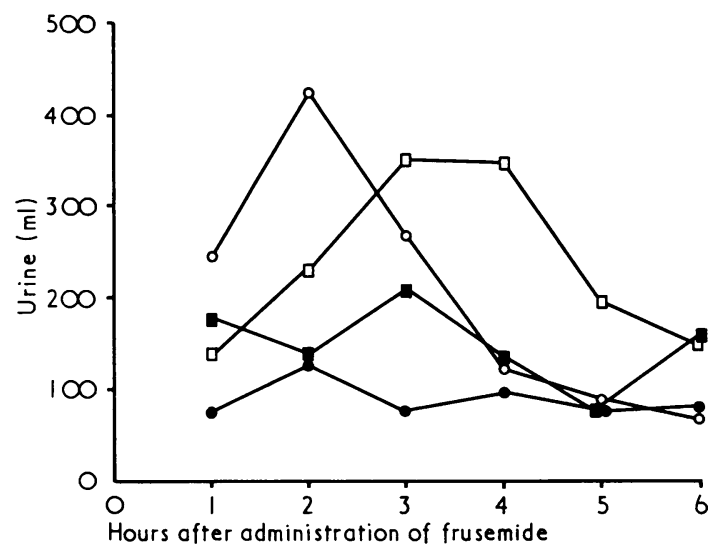

FIG. 1-Effect of oral frusemide $20 \mathrm{mg}$ and placebo in 14 Fig. 1-Effect of oral frusemide $20 \mathrm{mg}$ and placebo in 14 patients on placebo. $O=$ Normal subjects on frusemide. $=$ Patients on placebo. $O=$ Normal subjects on placebo.
$=$ Normal

TABLE I-Blood and Urine Values in 17 Epileptic Patients

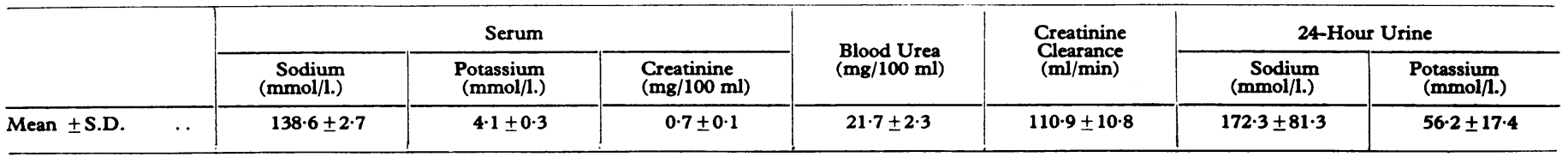


TABLE II-Diuretic Effect of Oral Frusemide in Epileptic Patients and Normal Subjects. Results expressed as Mean ( \pm S.D.) Urine Volumes (ml) after Urine Volume on Placebo Treatment had been subtracted from Volume on Frusemide Treatment at each Time Interval

\begin{tabular}{|c|c|c|c|c|c|c|c|c|c|c|c|c|}
\hline & & & & \multirow{2}{*}{ No. } & \multirow{2}{*}{$\begin{array}{l}\text { Dose } \\
(\mathrm{mg})\end{array}$} & \multicolumn{6}{|c|}{$\begin{array}{c}\text { Time after Administration of Treatment } \\
\text { (Hours) }\end{array}$} & \multirow[t]{2}{*}{ Total } \\
\hline & & & & & & 1 & 2 & 3 & 4 & 5 & 6 & \\
\hline \multicolumn{2}{|c|}{$\begin{array}{l}\text { Patients } \\
\text { Normal subjects }\end{array}$} & $\begin{array}{ll}n \\
\cdots\end{array}$ & $\because$ & $\begin{array}{l}14 \\
10\end{array}$ & 20 & $\begin{array}{r}-40 \pm 50 \\
172 \pm 26\end{array}$ & $\begin{array}{r}96 \pm 49 \\
308 \pm 53\end{array}$ & $\begin{array}{l}145 \pm 63 \\
186 \pm 46\end{array}$ & $\begin{array}{r}162 \pm 76 \\
24 \pm 22\end{array}$ & $\begin{array}{r}109 \pm 35 \\
0 \pm 17\end{array}$ & $\begin{array}{l}-7 \pm 57 \\
-8 \pm 16\end{array}$ & $\begin{array}{l}465 \pm 134 \\
683 \pm 66\end{array}$ \\
\hline$\overline{\mathbf{P}}$ & $\ldots$ & $\ldots$ & $\ldots$ & & & $<0.005$ & $<0.005$ & N.S. & N.S. & $<0.025$ & N.S. & N.S. \\
\hline \multicolumn{2}{|c|}{$\begin{array}{l}\text { Patients } \\
\text { Normal subjects }\end{array}$} & 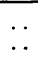 & 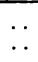 & $\begin{array}{l}17 \\
10\end{array}$ & $\begin{array}{l}40 \\
40\end{array}$ & $\begin{array}{r}18 \pm 24 \\
200 \pm 46\end{array}$ & $\begin{array}{l}110 \pm 30 \\
483 \pm 71\end{array}$ & $\begin{array}{l}189 \pm 38 \\
356 \pm 33\end{array}$ & $\begin{array}{r}206 \pm 48 \\
92 \pm 18\end{array}$ & $\begin{array}{l}45 \pm 64 \\
60 \pm 21\end{array}$ & $\begin{array}{r}40 \pm 42 \\
-19 \pm 27\end{array}$ & $\begin{array}{r}603 \pm 106 \\
1,191 \pm 82\end{array}$ \\
\hline $\bar{P}$ & $\ldots$ & $\ldots$ & $\ldots$ & & & $<0.0005$ & $<0.0005$ & $<0.0005$ & $<0.0005$ & N.S. & N.S. & $<0.005$ \\
\hline
\end{tabular}

TABLE III-Diuretic Effect of Frusemide $20 \mathrm{mg}$ given Intravenously to Epileptic Patients and Normal Subjects. Results expressed as Mean ( \pm S.D.) Urine Volumes (ml) after Urine Volume on Placebo Treatment had been subtracted from Volume on Frusemide Treatment at each Time Interval

\begin{tabular}{|c|c|c|c|c|c|c|c|c|c|c|}
\hline & & \multirow{2}{*}{$\begin{array}{l}\text { No. } \\
\text { Studied }\end{array}$} & \multicolumn{7}{|c|}{$\begin{array}{c}\text { Time after Administration of Treatment } \\
\text { (Minutes) }\end{array}$} & \multirow[t]{2}{*}{ Total } \\
\hline & & & 15 & 30 & 45 & 60 & 75 & 90 & 105 & \\
\hline $\begin{array}{l}\text { Patients . . . } \\
\text { Normal subjects }\end{array}$ & $\because$ & $\begin{array}{r}12 \\
5\end{array}$ & $\begin{array}{l}133 \pm 15 \\
365 \pm 34\end{array}$ & $\begin{array}{l}144 \pm 11 \\
256 \pm 5\end{array}$ & $\begin{array}{l}125 \pm 11 \\
209 \pm 8\end{array}$ & $\begin{array}{l}102 \pm 11 \\
141 \pm 4\end{array}$ & $\begin{array}{r}48 \pm 12 \\
101 \pm 7\end{array}$ & $\begin{array}{l}21 \pm 5 \\
58 \pm 7\end{array}$ & $\begin{array}{r}-4 \pm 4 \\
6 \pm 4\end{array}$ & $\begin{array}{r}570 \pm 27 \\
1,136 \pm 72\end{array}$ \\
\hline$\ldots$ & $\ldots$ & $\ldots$ & $<0.0005$ & $<0.0005$ & $<0.0025$ & N.S. & $<0.025$ & $<0.0125$ & $<0.01$ & $<0.0005$ \\
\hline
\end{tabular}

\section{Results}

ORAL FRUSEMIDE

The diuretic response in the patients was clearly delayed (figs. 1 and 2). Both the $20-\mathrm{mg}$ and $40-\mathrm{mg}$ dose produced a maximum diuresis at two hours in the normal subjects, whereas the peak was delayed until 3-4 hours in the patients. Furthermore, the total diuresis was considerably smaller in the patients. The differences between the urine volumes on active drug treatment and those on placebo are given in table II. The total diuresis over six hours in the patients was only $68 \%$ of that in normal subjects on the $20 \mathrm{mg}$ dose and only $51 \%$ of that of the normal subjects on the $40 \mathrm{mg}$ dose, the latter difference being significant.

\section{INTRAVENOUS FRUSEMIDE}

An immediate diuresis was observed in both the normal subjects and patients after intravenous injection of $20 \mathrm{mg}$ of frusemide, but the urine volumes were considerably smaller in the patients (fig. 3). The total diuresis at the end of 105 minutes in the patients was only $50 \%$ of that in the normal subjects (table III), the difference being statistically significant.

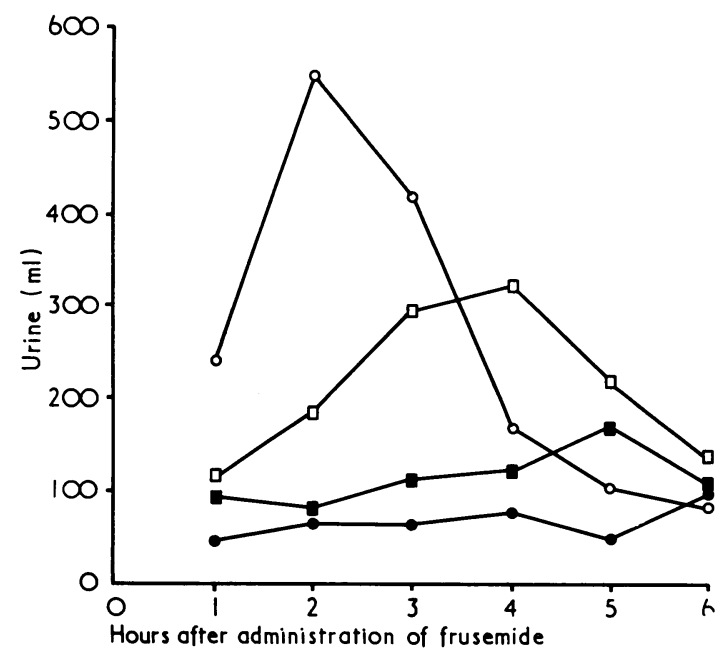

FIG. 2-Effect of oral frusemide $40 \mathrm{mg}$ and placebo in 14 patients and 10 normal subjects. See legend to fig. 1 for key.

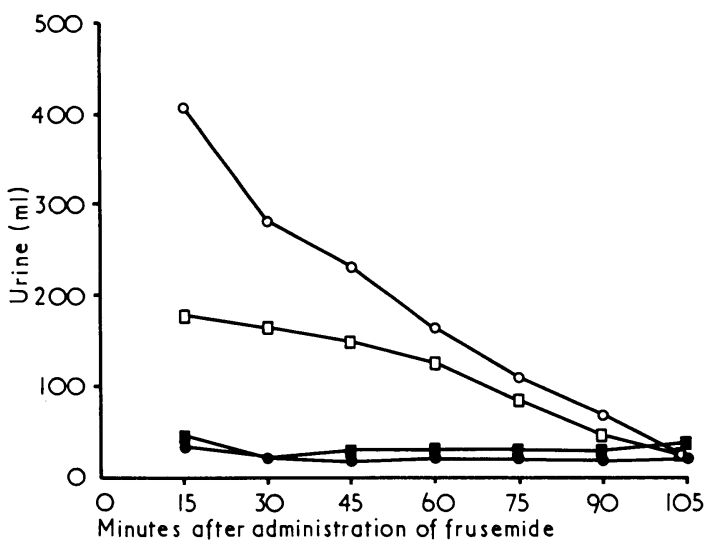

FIG. 3-Effect of intravenous frusemide $20 \mathrm{mg}$ and placebo in 12 patients and five normal subjects. See legend to fig. 1 for
key.

\section{Discussion}

It is clear from these results that the diuretic response to oral frusemide in chronic epileptic patients on anticonvulsant therapy is smaller than that in normal subjects and that this poor response is not overcome by intravenous administration. Though the malabsorption of the drug would explain the diminished effect of oral therapy this possibility is ruled out by the finding that the response to intravenous administration was equally poor. Thus a reduced sensitivity of the renal tubule to the diuretic action of the drug was probably the cause of the diminished response. It is unlikely, though it cannot be ruled out, that epilepsy per se was responsible for the altered sensitivity. On the other hand anticonvulsant drugs, particularly phenytoin, are known to have effects on the membrane of excitable cells and produce an increase in transport of sodium ions across the membrane by stimulating sodium-potassium adenosinetriphosphatase (Woodbury, 1969). The effect of phenytoin on the renal handling of sodium has not been studied in man, but experiments in dogs indicate that the renal tubular reabsorption of sodium is enhanced (Koch et al., 1962). It is possible, therefore, that the natriuretic action of frusemide is antagonized by this sodium-retaining action of phenytoin. Each of the patients in our study was receiving this drug.

Another possibility is that the apparent volume of distribution of frusemide was greatly increased in the patients and that this resulted in lower plasma concentrations of the drug. This alternative cannot be ruled out as we did not measure the 
plasma concentrations; to do so would obviously be illuminating.

The delayed response to oral therapy is more difficult to explain. The drug was taken about three-quarters of an hour after breakfast in both the normal subjects and patients and the nature of the meal was similar in the two groups. A similar time course of effect could therefore have been expected. As the response to intravenous frusemide was as prompt in the patients as in the normal subjects a renal cause for the delay cannot be postulated. A decreased rate of absorption of the drug from the gastrointestinal tract is possible, perhaps caused by a reduction in gastrointestinal motility. Decreased gastric emptying produced by propantheline has been shown to delay paracetamol absorption (Nimmo et al., 1973), and it is known from animal experiments (Woodbury, 1969) that spontaneous activity in gastrointestinal smooth muscle is greatly diminished by phenytoin.

Anticonvulsant drugs are potent hepatic enzyme inducers (Richens, 1974) and cause a considerably shortened plasma half life of many drugs. Increased metabolism on "first pass" through the liver can considerably reduce the plasma concentration of a drug which is metabolized by liver enzymes. Frusemide, however, is metabolized to a small degree (Lasix: International Furosemide Symposium, 1964) and therefore it is unlikely that enzyme induction would explain the abnormal response seen in this study.
The patients' urine volumes were higher than the normal subjects' after placebo treatment (figs. 1-3). Whether drinking habits account for this or whether phenytoin inhibits antidiuretic hormone release when used chronically, as has been shown after acute administration (Fichman et al., 1973), is uncertain. Obviously the diuretic effect of frusemide might be modified by such an action.

I thank Dr. Alan Richens for his advice and constant help, especially in writing this paper; Dr. John Laidlaw for his constant support and encouragement; the members of the staff at Chalfont Centre for Epilepsy for their co-operation; Dr. Peter R. Read of Hoech t Pharmaceuticals, for supplying the drugs etc. and for his help; and Mrs. J. Ashley and Mrs. R. Fazakerley for secretarial help.

\section{References}

Fichman, M. P., Kleeman, C. R., and Bethune, J. E. (1973). Archives of Neurology, 22, 45.

Lasix: International Furosemide Symposium (1964). Frankfurt, Hoechst.

Koch, A., et al. (1962). Physiologist, 5, 168

Nimmo, J., et al. (1973). British Medical fournal, 1, 587

Richens, A. (1974). British Fournal of Clinical Pharmacology. In press.

Woodbury, D. M. (1969). In Basic Mechanism of Epilepsies, ed. H. H. Jasper, A. A. Ward, and A. Pope, p. 647. London, Churchill.

\title{
Familial Trends in Low Birth Weight
}

\author{
FRANK JOHNSTONE, LESLEY INGLIS
}

British Medical fournal, 1974, 3, 659-661

\section{Summary}

The reproductive performance of sisters and sisters-inlaw of 185 women who had delivered "light-for-dates" and "premature expulsion" low birth weight infants was studied. Percentile birth weights were compared taking into account length of gestation, fetal sex, and the height, weight, parity, and smoking habits of the mother. Sisters of women who had delivered light-for-dates babies had lighter babies than the general population, their sistersin-law, or the sisters of women in the premature expulsion group. These other groups, however, had the expected distribution of percentile birth weights. Data on familial trends in smoking habits and unknown gestation are also presented. The results are consistent with the theory that the mother's own intrauterine experience affects her reproductive performance but could also be explained by shared family learning experience of as yet unidentified microsocial factors related to pregnancy performance.

\section{Introduction}

In recent years much attention has been paid to the recognition and management of infants with intrauterine growth retardation. These infants are associated with a significant increase

\footnotetext{
Department of Obstetrics and Gynaecology, Aberdeen Maternity Hospital, Aberdeen AB9 2ZD
}

FRANK JOHNSTONE, M.B., M.R.c.o.G., Registrar

Centre for Social Studies, Aberdeen

LESLEY INGLIS, M.A., Research Fellow in perinatal mortality (Gruenwald, 1969) and are at an increased risk in the neonatal period (Bard, 1970). When compared with control groups at follow-up examination they also seem to be smaller and have poorer physical development (Van den Berg and Yerushalmy, 1966; Tarumoto, 1966; Fitzhardinge and Steven, 1972 a), an increased incidence of speech defects, a poorer school performance (Fitzhardinge and Steven, 1972 b), and possibly suffer from intellectual impairment (Wiener, 1970). Growth retardation seems more commonly to be due to failure of uteroplacental support rather than low growth potential of the fetus, and the aetiology of this is not clearly understood.

One explanation suggested by Ounsted and Ounsted (1966) is that intrauterine growth is determined by a maternal regulating factor, and they emphasized that mothers of "light-fordates" infants tend to have no large babies and seem regularly to constrain the intrauterine growth of their young. Furthermore, they suggested that the mother's own intrauterine experence affected her subsequent reproductive performance (Ounsted and Ounsted, 1968)

This study was devised to compare the reproductive performance of sisters and sisters-in-law (brothers' wives) of women who had produced infants of low birth weight on the basis that their sisters to a certain extent had shared their intrauterine experience, while their sisters-in-law, though from similar social class, had not.

\section{Methods}

The data were collected in Aberdeen, which offers particular advantages for this type of study. The population is socially varied but ethnically homogeneous and until recently migration in and out of the city has been low. Since 1948 well over $80 \%$ of all births have taken place in the one teaching maternity hospital, and centralized comprehensive records of all pregnancies are available. During this time also particular attention has been paid to the collection and recording of data. 